\title{
演題番号15
}

\section{有血充填，無血充填体外循環における 血清及び，尿中の溶血につんて}

安城更生病院

$\begin{array}{llllll}\text { 中 } & \text { 前 健 二 竹 中 利 尾 } \\ \text { 荒 木 } & \text { 正 修 筒 井 信 幸 }\end{array}$

\section{はじめに}

開心術に扣ける体外循環灌流の血液に与兄る影 響は, 赤血球破壊（溶血）をはじめ, 白血球减少 血小板減少，血清のタンパク変性などを生じ，乙 れらの影響の中でも赤血球破壊は, 体外循環灌流 における最大の問題であり, 体外循環灌流の許容 時間をも左右するといえる。乙の赤血球破壊の原 因として，ポンプによるオクリューション及び， 心腔内血吸引, 気胞型人工肺に打けるバブリング などが知られている。しかし，体外循環灌流にお ける溶血の定量的数值の報告は数少ない.そこで， 当病院に打いて 1980 年 8 月〜 1982 年 2 月までの 開心術症例 151 例を検討した結果, 無血充填体外 循環では 28 例中 1 例 $(3.6 \%)$ ，有血充填体外循 環では 123 例中 28 例 $(22.8 \%)$ の肉眼的溶血尿 をみとめたので, 今回, 無血充填体外循環 6 例, 有血充填体外循環 11 例, 計 17 例の開心術症例飞 ついて血清及び，尿の溶血度（hemolys is）を時 間的経過を拈いて定量した結果を報告する.

\section{症例と方法}

症例は， 1983 年 4 月〜 1983 年 6 月までの当病 院で行なわれた開心術17例であり，表 1 亿示すご とく無血充填体外循環群では，年齢 16 ～58才ま での男性 3 名，女性 3 名，合計 6 名である．その 術式の内訳はMVR 2 例, OMC 1 例, AC バイパ ス術 1 例, ASD根治術 1 例, ECD根治術 1 例で あり，体外循環時間は 83 105 分，平均 $92.3 \pm$ 91.8 分で, 灌流量は $2.2 \sim 2.6 \mathrm{l} / \mathrm{m}^{2} / \mathrm{min}$, 平均 2.4 $\pm 0.13 \mathrm{l} / \mathrm{m}^{2} / \mathrm{m}$ in であった.

有血充填体外循環群では，年齢 5 ～61才までの
男性 9 名，女性 3 名で，その術式の内訳はMVR 1 例, V SD 根治術 3 例, TOF 根治術 1 例, AC バイパス術 6 例の 11 例である. 乙の体外循環時間 は $51 \sim 139$ 分, 平均 $110.6 \pm 31.3$ 分で, 灌流量は $2.4 \sim 2.6 \mathrm{l} / \mathrm{m}^{2} / \mathrm{min}$, 平均 $2.5 \pm 0.16 \mathrm{l} / \mathrm{m}^{2} / \mathrm{min}$ で あった.

人工肺は大人でBos-10， Harvey H-1500， 小児でBos-5，Shiley S-70，Harvey H-1300 を用い，回路は泉工社MTチューブを使用した.な 扣人工心肺充填量は大人で $2000 \sim 2200 \mathrm{ml}$ ，小児 で $1200 \sim 1300 \mathrm{ml}$ であり，充填液は乳酸リンゲル (ラクテック $\mathrm{pH} 8$ )，マニトール，ヘスパンダー, 強ミノファーゲンを用い，予測希釈率を無血体外 循環群では $34 \sim 41 \%$, 有血充填体外循環群では

表 I

\begin{tabular}{|c|c|c|c|c|}
\hline Ho. & Age & Sex & Diagnosis & Operation \\
\hline 1 & 40 & M & M R & MVR \\
2 & 42 & F & M R & MVR \\
3 & 16 & F & A SO & Radical ope \\
4 & 58 & M & A P & A- C Bypass \\
5 & 42 & M & M S & OMC \\
C & 17 & F & ECD & Radical ope \\
\hline
\end{tabular}

\begin{tabular}{|c|r|r|c|c|}
\hline No. & Aye & Sex & Diagnosis & Operation \\
\hline 1 & 56 & M & A P & A-C Bypass \\
2 & 56 & M & A P & A-C Bypass \\
3 & 5 & M & VSO & Radical ope \\
4 & 61 & F & A P & A-C Bypass \\
S & 64 & M & A P & A-C Bypass \\
B & 3 & M & VS D & Radical Ope \\
I & 36 & M & A P & A-C Bypass \\
I & 58 & M & A P & A-C Bypass \\
I & 2 & M & VSO & Radical Ope \\
11 & 2 & F & TOF & Radical ope \\
11 & 45 & F & M R & MYR \\
\hline
\end{tabular}


血液を $400 \sim 800 \mathrm{ml}$ 用い, 大人で $27 \sim 31 \%$ ，小 児で $23 〜 31 \%$ とした。

な枋資料は, 術前をコントロールとして人工心 肺回転中 (5 分, 15 分, 30 分以後停止まで15 分 毎），人工心肺停止時，停止後 1 時間， 5 時間， 7 時間, 16 時間後の血清及び, 尿を用い測定は, 通常血液検査で用いられるシアンメトへモグロビ ン法にて行なった。

\section{結 果}

表 IIは, 体外循環灌流中及び, 灌流後の血清中 へモグロビン值であるが, 灌流中の值は体外循環 により希釈されるために術前值をコントロールと して補正した.な敃灌流停止後は実測值で表わし てある.

表 II が示すごとく無血充填体外循環群では, 灌 流開始 5 分で 0. $7 \mathrm{mg} / \mathrm{dl}(3.33 \pm 5.50), 30$ 分 で0〜 $51 \mathrm{mg} / \mathrm{d} \ell(13.5 \pm 19.8) ， 45$ 分で0〜 81 $\mathrm{mg} / \mathrm{d} \ell(24 \pm 19.8) ， 60$ 分で2 $78 \mathrm{mg} / \mathrm{d} \ell(26.5$ $\pm 27.6) ， 75$ 分で $23 \sim 78 \mathrm{mg} / \mathrm{d} \ell(37.4 \pm 23.8)$, 90 分で44〜 $109 \mathrm{mg} / \mathrm{d} \ell(76.5 \pm 46.0)$ ，終了時で $4 \sim 121 \mathrm{mg} / \mathrm{dl}(43.7 \pm 40.7)$ であった.

有血充填体外循環群では, 灌流開始 5 分で 0 $31 \mathrm{mg} / \mathrm{dl}(9.0 \pm 9.6), 15$ 分で $0 \sim 67 \mathrm{mg} / \mathrm{d} l$

$(20.0 \pm 20.9), 30$ 分で0 135 mg/d $(38.5 \pm$ $37.2), 45$ 分で $12 \sim 300 \mathrm{mg} / \mathrm{d} \ell(71.0 \pm 84.8) 60$ 分で0〜 $173 \mathrm{mg} / \mathrm{dl}(76.0 \pm 56.7), 75$ 分で16〜 $299 \mathrm{mg} / \mathrm{d} \ell(107.4 \pm 99.6) ， 90$ 分で3〜237 m/ $\mathrm{d} l(107.0 \pm 87.9), 105$ 分で5〜288mg/d $\ell(104.0$ $\pm 126.4), 120$ 分で20 $292 \mathrm{mg} / \mathrm{d} \ell(122.3 \pm 12.1)$ 終了時で $33 \sim 254 \mathrm{mg} / \mathrm{d} \ell(114.1 \pm 76.99)$ であっ
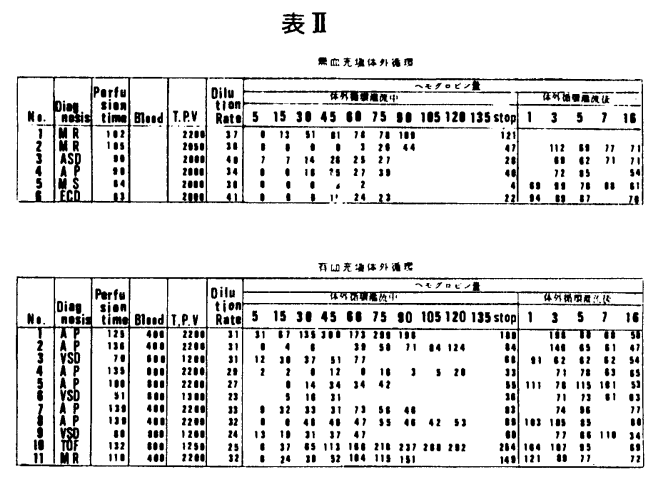

68
た. これをグラフに表わしたものが図 I であり， 灌流時間が延長するほどての両群に明らかな差が みられた。

一方灌流後は，表 II 示すごとく無血充填体外 循環群では終了 1 時間で $69 \sim 94 \mathrm{mg} / \mathrm{d} \ell(81.5 \pm$ $17.7), 3$ 時間で $69 \sim 112 \mathrm{mg} / \mathrm{d} \ell(88.2 \pm 18.1)$, 5 時間で $62 \sim 87 \mathrm{mg} / \mathrm{d} \ell(76.2 \pm 10.6), 7$ 時間で $71 \sim 88 \mathrm{mg} / \mathrm{d} \ell(78.7 \pm 8.6), 16$ 時間後で54 71 $\mathrm{mg} / \mathrm{d} \ell(65.4 \pm 7.6)$ であった.

有血充填体外循環群では, 終了 1 時間で 91 $164 \mathrm{mg} / \mathrm{d} \ell(118 \pm 28.0) ， 3$ 時間で $62 \sim 198 \mathrm{mg} /$ $\mathrm{d} \ell(98.0 \pm 40.8), 5$ 時間で $62 \sim 115 \mathrm{mg} / \mathrm{d} \ell(81.0$ $\pm 15.9), 7$ 時間で $61 \sim 101 \mathrm{mg} / \mathrm{dl}(75.1 \pm 2.1)$, 16 時間後では $34 \sim 77 \mathrm{mg} / \mathrm{d} \ell(61.1 \pm 13.7)$ であ り, 灌流後に扎いても 5 時間までは明らかな差が みられた。

肉眼的溶血尿をみとめた症例は, 表而に示すご とく AC バイパス術症例, TOF根治術症例, MVR 症例でいづれも有血充填体外循環であり, 血清へ モグロビン量は $100 \mathrm{mg} / \mathrm{dl}$ 以上であった。そして 肉眼的溶血尿のへモグロビン量は $50 \mathrm{mg} / \mathrm{d} \ell$ 以上で あった。

一方, 血清へモグロビン值 $100 \mathrm{mg} / \mathrm{d} l$ 以上を示 してから肉眼的溶血尿をみるにいたる時間は $\mathrm{AC}$ バイパス術症例で 30 分, TOF根治術症例で30分 MVR症例で 45 分であり, 平均 $35 \pm 8.67$ 分の差が みられた。

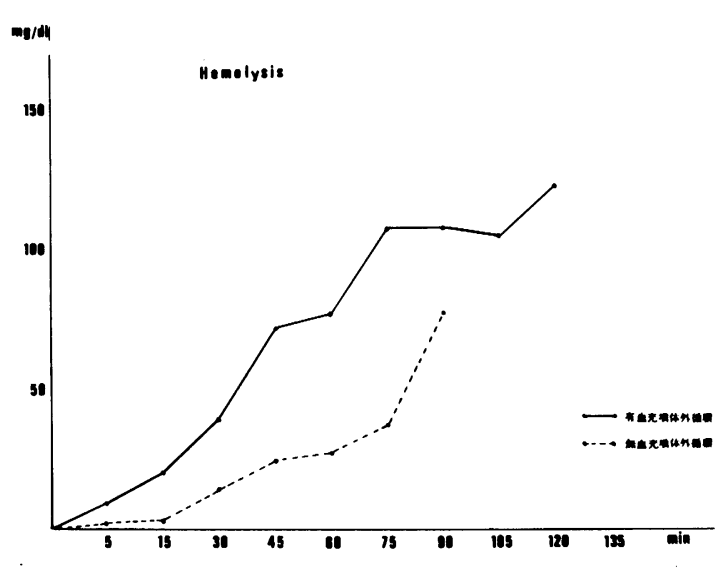

図1 


\section{表 III}

Hemelysis

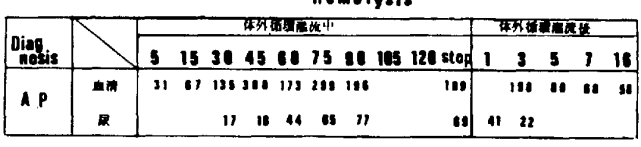

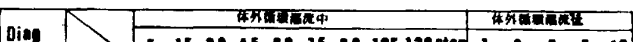

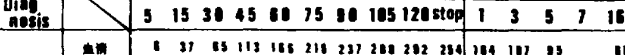

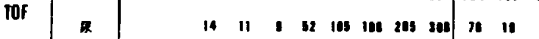

\begin{tabular}{|c|c|c|c|c|c|c|c|c|c|c|c|c|c|c|}
\hline \multirow{2}{*}{$\begin{array}{l}\text { Diag } \\
\text { nesis }\end{array}$} & & \multicolumn{8}{|c|}{ 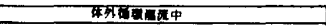 } & \multicolumn{5}{|c|}{ 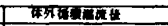 } \\
\hline & & 5 & 15 & 31 & 456 & 17 & 15 & 10 & 105120 stof & 1 & 3 & 5 & 7 & is \\
\hline O & m & 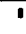 & 24 & 19 & 321 & & 115 & 111 & 149 & 121 & 19 & $n$ & & $n$ \\
\hline & n. & & & 10 & 3 & , & 34 & "s & $n$ & 44 & 22 & 11 & & \\
\hline
\end{tabular}

考 察

以上の成績より体外循環灌流中におりる血清一 モグロビン值の時間的変動は, 無血充填体外循環 群で 1 例を除き体外循環灌流開始 15 ～60 分, 平 均 $35.8 \pm 23.1$ 分で, 有血充填体外循環群では 5 30 分, 平均 $11.4 \pm 10.0$ 分でモグロビンをみとめ た.このことより無血充填体外循環群では灌流開 始 30 分前後飞，有血充填体外循環群では灌流開始 10分前後で溶血が始まると考光られる. 以後, 画 群ともに灌流時間に比例して血清へモグロビン值 は增加した。

一方，体外循環灌流停止後飞批いては，人工心 肺停止時より, 無血, 有血充填体外循環群ともに 減少した。無血充填体外循環群で人工心肺停止 後 $1 \sim 5$ 時間, 平埼 $3.4 \pm 1.7$ 時間, 有血充填体外 循環群も同様に $3 \sim 7$ 時間, 平均 $5.0 \pm 1.6$ 時間で ほぼコントロール值 $(54.9 \pm 10.3 \mathrm{mg} / \mathrm{dl})$ となり, 溶血の及ぼす影響は長くても人工心肺停止後 7 時 間までと考えられる。
溶血尿の出現は, 血清へモグロビン值で ${ }^{*} \mathrm{Cl}^{\circ}$ us は $100 \mathrm{mg} / \mathrm{d} \ell,{ }^{*} 川$ 崎は $110 \mathrm{mg} / \mathrm{d} \ell,{ }^{*} Y e r は 130$ $\mathrm{mg} / \mathrm{d} l,{ }^{*}$ 水野は $135 \sim 250 \mathrm{mg} / \mathrm{d} \ell$ 以上と文献飞よ ク多少異なる. しかし，今回，我々の行なった成 績によると血清へモグロビン值 $100 \mathrm{mg} / \mathrm{d} \ell$ (補正值) 以上を示す症例（無血充填体外循環群の MVR 症 例 1 例を除く) が，肉眼的溶血尿となり，さらに 血清へモグロビン值 $100 \mathrm{mg} / \mathrm{d} \ell$ 以上に達してから $30 \sim 45$ 分, 平均 $35 \pm 8.67$ 分後で肉眼的溶血尿 をみとめた。このてとより尿溶血が始まる30分以 前飞血清中での溶血が始まっていると考えられる.

結 語

1) 有血充填体外循環に対し，無血充填体外循環 では明らかに血清へモグロビン量が低值を示し 肉眼的溶血尿となりにくい。

2 ）無血充填体外循環では，灌流開始30分前後飞 有血充填体外循環では，灌流開始10分前後に溶 血が始まると考えられる.

3 ）溶血の影響は，無血充填体外循環で灌流停止 後 3 時間前後, 有血充填体外循環で灌流停止後 7 時間前後までである.

4) 血清中へモクロビン量 $100 \mathrm{mg} / \mathrm{d} l$ 以上で肉眼 的溶血尿となると考觉られる。

5 ) 肉眼的溶血尿のへモグロビン量は $50 \mathrm{mg} / \mathrm{d} \ell$ 以 上であると考えられる.

文 献

*体外循環技術 Volume 4, Number 2 Wint er 1978. 